\title{
Het kind in het middelpunt
}

Citation for published version (APA):

Kuijten, R. H. (1989). Het kind in het middelpunt. Rijksuniversiteit Limburg. https://doi.org/10.26481/spe.19890928rk

Document status and date:

Published: 28/09/1989

DOI:

10.26481/spe.19890928rk

Document Version:

Publisher's PDF, also known as Version of record

\section{Please check the document version of this publication:}

- A submitted manuscript is the version of the article upon submission and before peer-review. There can be important differences between the submitted version and the official published version of record.

People interested in the research are advised to contact the author for the final version of the publication, or visit the DOI to the publisher's website.

- The final author version and the galley proof are versions of the publication after peer review.

- The final published version features the final layout of the paper including the volume, issue and page numbers.

Link to publication

\footnotetext{
General rights rights.

- You may freely distribute the URL identifying the publication in the public portal. please follow below link for the End User Agreement:

www.umlib.nl/taverne-license

Take down policy

If you believe that this document breaches copyright please contact us at:

repository@maastrichtuniversity.nl

providing details and we will investigate your claim.
}

Copyright and moral rights for the publications made accessible in the public portal are retained by the authors and/or other copyright owners and it is a condition of accessing publications that users recognise and abide by the legal requirements associated with these

- Users may download and print one copy of any publication from the public portal for the purpose of private study or research.

- You may not further distribute the material or use it for any profit-making activity or commercial gain

If the publication is distributed under the terms of Article $25 \mathrm{fa}$ of the Dutch Copyright Act, indicated by the "Taverne" license above, 
Ontwerp wigmet onslag: Vorngeving:

Druk:
Mewc. H. wan der Neer - Groen

Audiowsuele Dienst Fitksuniversiteil Limburg Ald. Reprografie Rijksuniversitet Lumburg 


\section{Het kind in het middelpunt}

Rede

uitgesproken bij het aanvaarden van het ambt van gewoon hoogleraar in de kindergeneeskunde aan de Rijksuniversiteit Limburg te Maastricht op donderdag 28 september 1989

Dr. R.H. Kuijten 
Aan mijn ouders 
Mijnheer de Rector Magnificus,

Zeer geachre toehoorders.

De provincie Limburg telt ruim $1 \mathrm{miljoen}$ inwoners, waaronder bijna $250.000 \quad 0-18$ jarigen, de leeftijdsgroep waarop de kinderarts zijn specialistische deskundigheid richt. Het aantal geboorten in Nederland schommelt de laatste jaren tussen de 175.000 en 185.000 per jaar. De pediatrische doelgroep blijft vrij constant, zelfs wordt in de komende jaren een geringe stijging verwacht van het aantal geboorten.

De zuigelingensterfte en de perinatale sterfte zijn de afgelopen 15 jaar verder gedaald en geven nog steeds een tendens tot dalen te zien. De kleutersterfte en de sterfte van 5-14 jarigen zijn lager dan ooit.

1986 Zuigelingensterfte

Perinatale sterfte

Kleutersterfte (1-4 jr)

Schoolkindsterfte (5-14 jr)
7.8 per 1000 levendgeborenen

9.7 per 1000 geboorten

0.7 per 1000

0,2 per 1000

Met deze cijfers, die wel als graadmeter voor het peil van de kindergeneeskundige zorg worden beschouwd, behoort ons land tot een van de beste van de wereld.

Bij het bereiken van dit resultaat hebben vele factoren van maatschappelijke aard een rol gespeeld: vooruitgang van de sociale omstandigheden, verbetering van voeding, verhoging van het onderwijspeil van de bevolking, meer aandacht per kind in het kleiner blijvende gezin. In de gezondheidszorg hebben vooral de verbeterde bestrijding van besmettelijke ziekten en infecties, maar ook de vooruitgang van de perinatologische zorg en de chirurgie een gunstige invloed gehad op de sterftecijfers. De fraaie cijfers in onze 
sterftestatistieken hebben helaas bij sommige beleidsmakers tot de conclusie geleid dat de zorg voor het kind nu wel kan volstaan met een lage plaats op de lijst van prioriteiten in de gezondheidszorg. Dat is niet terecht.

Het handhaven van een lage sterfte vergt een continue inspanning. Van vele ziekten of afwijkingen is de dodelijke bedreiging weggenomen. Maar kinderen die een vroeger dodelijke ziekte nu, dank zij goede geneeskundige voorzieningen, weliswaar hebben doorstaan, maar hiervan restverschijnselen hebben overgehouden, zullen aangewezen blijven op verdere hulpverlening.

Wij zullen ons moeten inspannen om niet alleen de sterfte verder terug te dringen, maar vooral om door vroegtijdige opsporing, snelle diagnostiek, adequate behandeling te voorkomen dat er handicaps ontstaan, die de ontplooiing van het kind belemmeren of het kind levenslang aangewezen doen zijn op speciale voorzieningen en begeleiding.

Gegevens over ziekte en handicap, en voor de economen de financiële gevolgen daarvan, zouden ons, beter dan sterftecijfers een inzicht kunnen geven in de prioriteiten, die in de gezondheidszorg voor het kind gesteld moeten worden. Goed onderbouwde epidemiologische studies op dit terrein zijn dringend gewenst. In dit verband moet het tot bezinning stimuleren, dat ruim $25 \%$ van de 18 -jarige jongens die in 1987 werden gekeurd voor de militaire dienstplicht, voorgoed ongeschikt werden bevonden op grond van lichamelijke of geestelijke afwijkingen.

De veranderingen in de maatschappij en de vooruitgang van de geneeskunde hebben invloed gehad op het werk van de kinderarts, op de ouders en op de kinderafdeling in het ziekenhuis.

\section{De kinderarts.}

De verschillende levensfasen wan het opgroeiende individu hebben ieder hun specifieke geneeskundige problemen. Daarnaast komen vele ziekten zowel bij volwassenen als bij kinderen voor. Het bijzondere van de kinderleeftijd is dat een ziekteproces een aparte verschijningsvorm, een bijzonder beloop of extra gevolgen kan hebben, doordat het interfereert met de processen van groei en ontwikkeling. De tijd is 
gelukkig voorbij dat het kind beschouwd werd als een kleine vol wassene. Toch kom je nog wel eens de opvatting tegen, dat een kinderarts zich voornamelijk van een internist onderscheidt doordat hij kan volstaan met een kleinere stethoscoop (en ook met een kleiner inkomen).

De kinderarts heeft allereerst een taak bij de diagnostiek en behandeling van ziekten op de kinderleeftijd. Daarnaast is hij vertrouwd met preventie, vroegtijdige opsporing en begeleiding. Van de kinderarts wordt deskundigheid verwacht betreffende groei en ontwikkeling, zowel lichamelijk als geestel.jjk en sociaal, de problematiek rond de pasgeborene, voeding en voedingsstoomissen, immuniteit, infectieziekten, ziekten van organen en orgaansystemen in relatie tot de leeftijd, psychosociale vraagstukken en de specifieke eisen die de verschillende leeftijden stellen aan opvoeding en begeleiding. De algemene kinderarts moet dan ook gezien worden als een gespecialiseerde generalist voor kinderen.

De huidige generatie kinderartsen heeft duidelijke verschuivingen zien optreden in de dagelijkse werkzaamheden. Besmettelijke ziekten zoals tuberculose, kinderverlamming en roodvonk, zien wij nog maar zelden. Vele infecties, bijwoorbeeld bacteriele hersenvliesontsteking en longontsteking, kunnen dank zij antibiotica en chemotherapeutica effectief worden behandeld met kans op volledige genezing.

Verbeterd inzicht in de pathofysiologie van ziekteprocessen op de kinderleeftijd heeft geleid tot toename van de mogelijkheden tot interventie. Men denke slechts aan het profylactisch toedienen wan antiD-gammaglobuline, waardoor een rhesus-antagonisme in de zwangerschap voorkomen kan worden, de behandeling van fenylketonurie met aangepaste voeding, de behandeling van kinderen metcystic fibrosis, de ontwikkeling van de perinatologie met intrauteriene overplaatsing van ernstig bedreigde kinderen naar centra waar intensieve begeleiding van partus en neonatale periode mogelijk is. De spectaculaire vooruitgang van de radiodiagnostiek, de neonatale en cardiopulmonale chirurgie hebben eveneens een onmiskenbare inwloed gehad op het werk van de kinderarts. De toegenomen kennis van ziekten van organen en orgaansystemen heeft ook in de kindergeneeskunde tot het ontstaan van deelspecialismen geleid. Dit houdt het gevaar in, dat de kinderarts steeds meer medisch-technisch gaat denken en werken. Van de andere kant komen er signalen, die wijzen op een toename van de stoornissen 


\section{De kinderafdeling}

De zorg yoor de bedreigde pasgeborenen voltrekt zich tegenwoordig op de meeste platsen en ook bij ons, in aparte ruimten, de neonatale intensive care units, met allerlei technisch hoogwaardige voorzieningen.

Ook de afdeling voor grotere kinderen is de laatste jaren veranderd.

De huidige opvattingen over kinderverpleging en ouderparticiptatie hebben hun stempel gedrukt op de aanblik van de kinderafdeling. De starre regels zijn verdwenen.

Geen keurig opgemaakte bedden meer tijdens de ochtendvisite, geen stilte of voorzichtig gefluister als de dokter langskomt. Tussen of half onder de kinderbedden bevinden zich opklapbedden of matrassen van de ouders, het geluid van draagbare radio"s ontbreekt alleen op de kamers voor zuigelingen. Men ziet moeders of vaders of beide, die hun kind zelf verzorgen, meegaan naar de speelkamer, of die na een nacht slecht slapen in het ziekenhuis, even liggen uit te rusten in het bed van hun kind, dat zelf inmiddels met infuus en al naar de speelkamer is gegaan. De atmosfeer is huiselijker geworden, minder bedreigend voor het kind en dat is goed.

De populatie kinderen op de kinderafdeling is eveneens veranderd. Veel van de problemen die vroeger tot opname leidden, worden nu poliklinisch afgewerkt. Dit maakt dat de populatie van een kinderafdeling bestaat uit ernstig zieke en bewerkelijke kinderen, die veel aandacht vragen van verpleging en kinderarts. De drang om een ziekenhuisopname alsmaar korter te maken begint wel overdreven vormen aan te nemen. Wanneer in een kort tijdsbestek talrijke medici en paramedici, soms van meerdere disciplines op het opgenomen kind en zijn ouders afschieten, wanneer hele batterijen onderzoek achter elkaar afgewerkt moeten worden zonder dat de resultaten van de eerste onderzoekingen overwogen kunnen worden, alvorens de volgende worden afgesproken, wanneer er geen dag zonder onderzoek of ingreep voorbij mag gaan, dan zijn wij op de verkeerde weg. Een dergelijke planning leidt tot stress op de afdeling en is belastend voor de ouders en thet kind, dat geen kans krijgt even tot rust te komen.

Op zo'n manier wordt een ziekenhuisopname een traumatische ervaring. Hetzelfde geldt voor de poging het kind eerder mee naar huis te nemen 
dan raadzaam is. De verschuiving van het pediatrisch werk wan de kliniek naar de polikliniek stelt bijzondere eisen aan de organisatie, vooral wanneer hetkinderen betreft die een multidisciplinaire benadering vragen. Patientgericht werken betekent ook hier het aanbieden van een geintegreerde zorg, b.v. door het organiseren van gezamenlijke spreekuren en besprekingen van kinderarts met andere specialismen en paramedische disciplines. 


\section{Academische kindergeneeskunde in Maastricht.}

Het wezenlijke van een academische afdeling is de aandacht voor onderwijs en onderzoek, beide onlosmakelijk verbonden met een geavanceerde patientenzorg.

Wij zullen deze drie aspecten afzonderlijk bezien.

\section{Het onderwijs.}

Met genoegen , misschien ietwat omgeven door nostal gische gevoelens, denk ik terug aan de ouderwetse hoorcolleges, gegeven door eminente docenten als de internist Borst, de chirurg Boerma, de neuroloog Biemond, in het Binnengasthuis en het Wilhelmina Gasthuis te Amsterdam in de vijftiger jaren. Deze colleges werden druk bezocht, zelfs op zaterdag en zelfs in tentamentijd. Ze waren degelijk voorbereid, de patienten zorgvuldig geselecteerd. De docenten waren leermeesters in de ware zin van het woord. Zij demonstreerden, ontvouwden gedachten en lieten de student delen in hun inzicht en ervaringen.

Hoe anders is het nu, tijdens de onderwijssessie aan de Medische Faculteit in Maastricht. Staat $U$ mij toe dit even toe te lichten voor de "Hollanders", zoals alle niet-Limburgers hier worden genoemd.

De geneeskunde wordt hier niet vaks-gewijs benaderd. Geen onderwijs door de anatoom, de internist of de chirurg, maar een in blokken van enkele weken ingedeelde, probleemgeoriënteerde studlie, waarin onderwerpen als buikklachten, pijn op de borst, bloedverlies worden bestudeerd, steeds aan de hand van een casus: dat is een papieren patient. De studenten komen in groepen van 12 man $2 x$ per week bijeen in aanwezigheid van een tutor, die niet inhoudsdeskundig behoeft te zijn. De studenten bespreken de casus, en verdiepen zich de rest van de week in de vragen die door het ziektebeeld werden opgeroepen. $\mathrm{Zij}$ rapporteren aan elkaar en corrigeren elkaar zo mogelijk. Een 
inhoudsdeskundige wordt alleen geraadpleegd of opgeroepen als men er niet uitkomt. De casussen in ieder blok zijn zorgwuldig geselecteerd, de leerdoelen zo duidelijk mogelijk omschreven door een blokplanningsgroep, samengesteld uit docenten van verschillende gebieden. Daarnaast wordt veel aandacht besteed aan de training van vaardigheden, zowel medisch-technisch alls in gesprekstechnieken.

Maar het is niet mijn bedoeling $U$ hier een uiteenzetting te geven wan de verschillende onderwijssystemen en hun merites. Het probleemgerichte onderwijs van Maastricht heeft naam gemaakt in ons land en daarbuiten. Het leert de student zelf zijn weg te vinden.

Het kweekt een attitude om problemen zelf op te lossen, en benadert dat niet het uiteindelijke doel van het onderwijs : het opleiden van zelfstandig denkende mensen die in staat zijn vraagstukken te analyseren, gegevens te verzamelen en kritisch te beoordelen en daaruit conclusies te trekken of tot syntheses te komen?

En toch, denk ik, mist de Maastrichtse student zijn leermeester, zijn inspirator, zijn Borst, Biemond of Boerema, die hem in een vroeg stadium klinisch leert kijken en hem als gids kan dienen op zijn ontdekkingstocht in het bos van ziekten en afwijkingen.

Hierbij raken wij aan nog een belangrijk aspect van het onderwijs, dat moeilijk meetbaar, nauwelijks toetsbaar is: hoe dragen wij aan de student iets over van het enthousiasme voor het vak, van de belangstelling voor de patient, de medemens, die in de arts meer zoekt dan alleen een deskundig reparateur van tekortschietende organen ?

Is de persoon van de docent daarbij wel te missen?

In het Maastrichtse onderwijssysteem verdient het kind speciale aandacht. Het kind is in zijn ontwikkeling tot volwassenheid voortdurend bezig met processen van groei en rijping, zowel lichamelijk als psychisch en sociaal. Kennis van deze processen alleen is echter niet voldoende. De ziekten, afwijkingen, factoren die een bedreiging vormen voor de gezondheid van volwassenen, krijgen op de kinderleeftijd een extra dimensie doordat zij op het groeiende individu een ander effect kunnen hebben dan bij de volwassene en daarenboven een harmonische ontplooing van het kind kunnen belemmeren.

Alleen een goed inzicht in deze complexe materie kan de basis vormen 
yoor een adequate diagnostiek, behandeling en begeleiding van het zieke kind. Het zal duidelijk zijn, dat deze problematiek niet voldoende tot haar recht komt door werspreid over de verschillende blokken hier en daar een kindercasus op te nemen.

Met voldoening kan dlan ook geconstateerd worden dat bij de voorbereiding van het nieuwe onderwijs-curriculum een theel blok aan de groei en de ontwikkeling van het kind is gewijd: een stap in de goede richting.

Het niveau van de zorg voor het zieke kind in de maatschappij wordt in hoge mate bepaald door de zorg in de eerste lijn. Het is de huisarts, die uitmaakt of en wanneer en door wie hulp verleend gaat worden. Ongeveer $40 \%$ van de consulten van de huisarts heeft betrekking op een kind. Daarom is de tijd, besteed aan scholing van de huisarts, goed bestede tijd.

Het onderwijs aan de aanstaande huisarts zal zich vooral richten op algemene aspecten van de Kindergeneeskunde: groei en rijping, zowel somatisch als psychosociaal, infectie en afweer, voeding en voedingsstoornissen, leer- en gedragsstoornissen.

Daarnaast dient extra aandacht besteed te worden aan de grens tussen wat nog als variatie van het normale beschouwd mag worden en wat afwijkend, pathologisch is. Deze grens is inde verschillende leeftijdsfasen niet altijd gemakkelijk te zien. Uitgebreid onderwijs in puur pediatrische ziektebeelden is veel minder nodig. Zolang de kindergeneeskunde geen georganiseerde inbreng heeft in de thuisartsenopleiding zelf, zal ons onderwijs een ruime plaats moeten innemen in het curriculum van de basisarts.

Deopleiding van de aanstande kinderarts is een stimulerende activiteit, die onmisbaar is voor een academische afdeling. Wij verwachten in 1991 zo ver te zijn, dat wij in samenwerking met kinderartsen uit de regio een volledige opleiding kunnen waarmaken.

Het woert te ver om hier gedachten te ontvouwen over de postacademische scholing van de kinderarts zelf. Op dit terrein zijn landelijk ontwikkelingen gaande, waaraan wij met enthousiasme zullen participeren. 


\section{Het onderzoek.}

Klinische vraagstellingen kunnen leiden tot diepgaand fundamenteel onderzoek.

Het nefrotisch syndroom, dat is een ziektebeeld waarbij de nieren tijdens het filtreren van het bloed eiwitten doorlaten, die ze nommal behoren vast te houden, is daarvan een voorbeeld. Wat is de oorzaak van het eiwitlek?

Deze vraag heeft geleid tot uitgebreide research, ook dierexperimenteel, voornamelijk in laboratoria voor pathologische anatomie, immunologie, biochemie, moleculaire biologie.

Volgens de huidige hypothesen spelen stoornissen van de immunoregulatie en veranderingen van electrisch geladen moleculen binnen de glomerulair basale membraan, het lekkende zeef bij deze aandoening, een belangrijke rol.

Onderzoek naar de beste behandeling van kinderen met een nefrotisch syndroom maakte het noodzakelijk over grote aantallen patienten te kunnen beschikken, wilde men binnen een redelijke termijn statistisch bewerkbare gegevens kunnen produceren.

Omdat voor dergelijke onderzoeken de eigen patientenpopulatie ook van grote centra te klein was, werd samenwerking met andere klinieken noodzakelijk. Zo slaagde in 1966 Henry Barnet in het Albert Einstein College of Medicine in New York er in een Internationale groep kindernefrologen te laten samenwerken in de "International Study of Kidney Diseases in Children", waardoor 500 kinderen met een nefrotisch syndroom prospectief konden worden gevolgd en diverse behandelschema"s konden worden vergeleken. Dit initiatief heeft de internationale contacten tussen kindernefrologen aanzienlijk bevorderd en is veel nagevolgd, onder andere door de "Arbeitsgemeinschaft für Pädiatrische Nephrologie" waaraan ook wij deelnemen.

Multicenter-studies bieden bijzondere perspectieven voor klinisch, patientgericht onderzoek.

Gelukkig de klinicus die woor zijn vraagstelling een gewillig oor vindt bij de basiswetenschappen en wiens problematiek past in de zwaartepunten van het facultair onderzoek. 
Voor de kindergeneeskunde in Maastricht zijn de mogelijkheden niet ongunstig.

Door onze neonatologen, de collegae Blanco, Maertzdorfen Degraeuwe wordt een bijdrage geleverd aan het onderzoek in het kader van het zwaartepunt perinatologie, waarbij vraagstukken rond de pathofysiologie van de neonatale ademhaling zowel dierexperimenteel als klinisch worden benaderd.

Verder wordt in samenwerking met de plaatselijke huisartsen door collega van der Meer, een onderzoek gedaan van kinderen met. recidiverende buikpijn. Gezocht wordt naar organische en psychische oorzaken en naar het effect van therapeutische maatregelen.

Met medewerking van een aantal jeugdartsen wordt door collega Schrander een epidemiologische studie verricht naar het wó́rkomen van voedselallergie bij 0-1 jarigen.

De daaruit voortkomende vragen geven aanleiding tot meer basaal onderzoek op het gebied van onder meer de pathologische anatomie, de immunologie en allergologie. Deze onderzoeken maken deell uit van het facultaire zwaartepunt "Voeding". De kindergeneeskunde verwacht vanuit het gezichtspunt 'groei en rijping" een wezenlijke bijdrage aan deze onderzoekslijn te kunnen leveren. De onlangs gestarte studie door de collegae Westdorp en Gerver naar de lichaamsproporties en de lichaamssamenstelling van pasgeborenen en de invloed daarop van. verschillende soorten voedingen is daarvan een voorbeeld.

In Limburg ${ }_{n}$ en zeker in Zuid-Limburg verkeren wij in een bijzondere positie doordat het aantal kinderartspraktijken gering is en de onderlinge verstandhouding een goede samenwerking mogelijk maakt.

Deomstandigheden lijken gunstig voor epidemiologische en multicenter studies. Ik hoop dat wij erin zullen slagen om, samen met de kinderartsen uit de regio, initiatieven voor patientgericht onderzoek te ontplooien op het terrein van de algemene kindergeneeskunde of haar deelgebieden.

\section{De patientenzorg}

Het is de taak van een Academische Kinderafdeling te kunnen voorzien in de behoefte aan pediatrische topzorg in de regio. Daartoe is niet alleen 
concentratie van kostbare voorzieningen op het gebied van diagnostiek en behandeling nodig, maar ook de aanwezigheid van specifieke deskundigheid en wetenschappelijke activiteit in de deelgebieden van de kindergeneeskunde. Bij de hiertoe benodigde investeringen geldt dat de kost voor de baat zal moeten uitgaan.

Het zieke kind, dat deelspecialistische behandeling behoeft, is het meest gediend met een deskundige behandeling, zo dicht mogelijk bij huis. Alleen dan kunnen de ouders daadwerkelijk een belangrijke rol spelen bij de verzorging van hun kind, zonder de rest van het gezin volledig te ontwrichten.

Ook wordt het ontslag uit het ziekenhuis bespoedigd als een frequente poliklinische controle niet wordt belemmerd door lange reistijden. Een pediatrisch eindstation in de regio is daarom niet alleen voor het zieke kind en zijn ouders, maar ook voor de ziektenkostenverzekeraars een aanlokkelijk perspectief.

Het zal niet mogelijk zijn in Maastricht op alle gebieden van de kindergeneeskunde een topreferentiefunctie te vervullen.

Een dergelijk streven zou ook niet stroken met de landelijke pogingen om tussen de academische kinderklinieken tot centralisatie en zwaartepuntvorming te geraken. Het concentreren van speciale voorzieningen in slechts enkele academische centra heeft het voordeel, dat in deze centra ervaring kan worden verkregen en onderzoek kan worden opgezet betreffende zeldzaam voorkomende afwijkingen.

Toch kan ik mij niet onttrekken aan de gedachte dat sommige van de pogingen om de behandeling van bepaalde afwijkingen te concentreren (en dan natuurlijk in de eigen kliniek) niet uitgaan van het belang van het kind, maar ook wel eens worden ingegeven door economische motieven en de vrees dat bij spreiding van voorzieningen de eigen exclusiviteit wordt geschaad. Een goede samenwerking tussen de academische kinderafdelingen kan veel van de inhoudelijke problemen oplossen.

De eerstkomende tijd zall het uitbouwen van de patientenzorg onze hoogste prioriteit hebben.

Binnen de kindergeneeskunde zijn verscheidene deelspecialismen ontstaan waarvan wij er sommige in Maastricht al hebben of zullen ontwikkelen, in samenwerking met andere pediatrische centra in het 
land of met locale verwante specialismen voor vol wassenen. Wij zullen enkele van deze subspecialismen de revue laten passeren, omdat ze voor onze situatie zo van belang zijn.

\section{Neonatologie.}

De geavanceerde zorg voor de pasgeborene heeft geleid tot ontplooing van de neonatologie, die samen met de obstetrie, vorm en inhoud heeft gegeven aan perinatologische centra, zoals die in alle universitaire klinieken tot ontwikkeling zijn gekomen. Ook in Maastricht kunnen wij ons verheugen in een bloeiende neonatologie, die de regionale topreferentiefunctie heeft waargemaakt.

Onlangs heeft collega Blanco U in zijn oratie uitvoerig ingelicht over de stand van zaken in dit zo spectaculaire gebied van de kindergeneeskunde.

\section{Gasteroenterologie en voeding.}

Enkele aspecten van dit vakgebied krijgen in onze kinderafdeling reeds bijzondere aandacht, vooral door de inbreng wan collega Forget. Wij streven er naar de gastroenterologie verder uit te bouwen en de locale mogelijkheden voor meer fundamentele research op dit gebied te benutten. Voeding is immers een van de facultaire zwaartepunten van onderzoek. Hypothesen over relaties tussen groei en rijping van het maag-darm stelsel en het ontstaan van voedselallergie, vragen om experimentele en klinische toetsing. Trouwens, voedselallergie is erg in de mode maar de definitie alleen al geeft grote problemen.

\section{Kinderlongziekten.}

Ongeveer $10 \%$ van de kinderen in ons land heeft klachten van chronische aspecifieke aandoeningen van de luchtwegen, CARA, genoemd. Meer dan de helft van deze kinderen zal ook in de wolwassenheid last hebben van deze aandoeningen, die bij sommigen van hen in het latere leven tot invaliderende longafwijkingen kunnen leiden.

Vroegtijdige behandeling is essentieel en vereist een goed inzicht in de pathofysiologie en een ruime ervaring in het omgaan bij kinderen met de talrijke middelen, die beschikbaar zijn om allergische ontsteking en vernauwing van de luchtwegen te voorkomen of te genezen.

Betrouwbare metingen wan de longfunctie zijn onontbeerlijk om de mate van luchtwegvernauwing en de reactie op medicamenten objectief 
te kunnen vastleggen. Op de kinderleeftijd stelt dit extra eisen aan apparatuur en personeel. Om de grote groep kinderen met aandoeningen van de luchtwegen, waaronder de kinderen met Cystic Fibrosis, te kunnen laten profiteren van recente aarwinsten op het gebied van longfunctieonderzoek en behandelwijzen, is het wenselijk, dat er in onze regio een centrumfunctie wordt ontwikkeld voor pediatrische longaandoeningen, met andere woorden, dat de pediatrische pulmonologie in Maastricht tot een subspecialisme wordt uitgebouwd. Wij zullen hiervoor aansluiting zoeken bij de in ons ziekenhuis aanwezige longfunctieafdeling en de afdeling longziekten voor volwassenen. De eerste contacten zijn gelegd en veelbelovende ontwikkelingen zijn mogelijk.

\section{Kindercardiologie.}

Met de komst van collega Pulles, recentelijk versterkt met collega Hoorntje heeft de kindercardiologie in Maastricht vaste voet gekregen. De stimulerende mogelijkheden, die de afdeling cardiopulmonale chirurgie hierbij biedt, hebben ertoe geleid, dat de regionale functie van de kindercardiologie ten volle kan worden vervuld. Door de internationale faam van de Maastrichtse cardiologie op het terrein van de ritmestoornissen, ligt het in de lijn der verwachting, dat wij zullen trachten hierbij aansluiting te vinden bij het uitzetten van onderzoekslijnen.

\section{De Pediatrische endocrinologie.}

Processen van groei en ontwikkeling behoren tot het wezen van de kindergeneeskunde. Het is de pediatrische endocrinologie die zich meer gedetailleerd bezig houdt met de mechanismen die de groei bepalen, reguleren of verstoren. Steeds meer kennis van algemeen werkende en weefselspecifieke stoffen, die de groei beïnvloeden zal de kinderarts mogelijkheden geven om corrigerend op te treden als de groeiprocessen gestoord raken. De beschikbaarheid van door recombinant technology verkregen humaan groeihormoon is daarvan een voorbeeld.

Groei uit zich in toename van lichaamslengte en gewicht, maar ook in verandering van proporties en samenstelling van het lichaam. Dit is speciaal het belangstellingsveld van collega Gerver. Van het inbrengen van deze aspecten in het onderzoeksproject voeding stellen wij ons veel voor. 


\section{Kindernefrologie}

De nierfunctie wordt bedreigd, soms al intra-uterien, door aangeboren nierafwijkingen en belemmeringen van de urineafvoer. Na de geboorte komen daar nog urineweginfecties en nierontstekingen bij. Een aantal kinderen met deze aandoeningen zal samen met de kinderuroloog worden behandeld. Vaak is jarenlange begeleiding nodig met speciale aandacht voor de bloeddruk, het dieet en het bestrijden of voorkomen van infecties.

Wij dienen in Maastricht te kunnen beschikken over adequate voorzieningen voor het behandelen van acute nierinsufficientie bij kinderen.

De chronische nierfunctievervangende behandeling door middel van dialyse en niertransplantatie stelt op de kinderleeftijd bijzondere eisen aan medische, technische en psycho-sociale voorzieningen en is alleen in teamverband op verantwoorde wijze uit te voeren. In het kader van ons streven om het zieke kind zo dicht mogelijk bij huis te laten, zullen wij voor de behandeling van kinderen met chronische nierinsufficientie een aan de leeftijd aangepaste samenwerking proberen te realiseren met centra voor dialyse en transplantatie.

\section{Kinderoncologie.}

Toepassing van de ver voortgeschreden kennis op dit gebied geeft aan kinderen met kwaadaardige nieuwvormingeneen grote kans op genezing, veelal door een juiste combinatie van chemotherapie, bestraling en chirurgie. Het gemiddelde 5-jaars overlevingpercentage ligt omstreeks de $60 \%$, voor de Wilms tumor en het retinoblastoom zelfs bij de $90 \%$. Niet alleen om de overlevingskans te vergroten maar ook om het aangedane kind de grootst mogelijke kans op volledig herstel met de minst riskante therapieën te kunnen bieden, zal de behandeling van kinderen met maligne aandoeningen in uiterst geschoolde handen moeten liggen, waardoor verwijzing naar een centrum niet altijd valt te vermijden.

Toch zijn het juist deze kinderen die door hun ziekte en door de bijwerkingen van de behandelschema's de nabijheid van vertrouwde personen, bij voorkeur de ouders, extra hard nodig hebben.

In samenwerking met de kinderoncologische centra in Amsterdam en Nijmegen verwachten wij in het AZM ook op dit terrein over de benodigde expertise te kunnen beschikken. 
Nog drie gebieden van de kindergeneeskunde vragen onze speciale aandacht: de adolescenten, de acute pediatrie en het chronisch zieke kind.

\section{De adolescenten.}

De adolescentie, de periode van overgang tussen kinderleeftijd en volwassenheid, wordt slechts vaag begrensd door de kalenderleeftijd van 14-19 jaar, maar wordt meer bepaald door de lichamelijke ontwikkeling en geestelijke rijpheid van het individu.

De adolescent komt in het ziekenhuis niet tot zijn recht tussen de schoolkinderen, maar ook niet tussen volwassenen en bejaarden. Wij streven derhal ve naar een afdeling met voorzieningen voor adolescenten waar uiteraard de eigen behandelend specialist van de patient de eindverantwoordelijke blijft voor het medisch handelen.

Problemen rond alcohol, drugs, sexualiteit, suicide, spelen vooral in deze leeftijdsgroep. Toch ligt het bijzondere van een afdeling voor adolescenten of jongeren niet zozeer in de leeftijd-specifieke pathologie, maar meer in het vlak van de medische, verpleegkundige en psychosociale benaderingen de aanwezigheid van bijzondere faciliteiten woor privacy, scholings- en recreatieve activeiten, contacten met leeftijdsgenoten, vrienden en famillie. Het stemt tot optimisme dat, althans in de nieuwbouw, aan de behoefte aan dergelijke voorzieningen kan worden voldaan.

\section{De acute pediatrie.}

Wanneer vitale functies als bewustzijn, ademhaling, nierfunctie en circulatie bedreigd worden of gestoord zijn, is deskundige bewaking nodig met de mogelijkheid direct te kunnen ingrijpen bij calamiteiten. Concentratie van patienten die dergelijke voorzieningen behoeven, heeft plaats op een afdeling voor Intensive Care. Dergelijke afdelingen voor pasgeborenen zijn al niet meer weg te denken uit de academische ziekenhuizen. In enkele universitaire kinderklinieken zijn afdelingen ontstaan voor intensive care voor kinderen ouder dan pasgeborenen en sommige kinderartsen hebben zich hierin gespecialiseerd. 
In zulke afdelingen zijn niet alleen alle faciliteiten aanwezig voor bewaking en acute ingrepen, maar wordt ook voldaan aan de eisen, die specifiek zijn voor een kinderafdeling: kindvriendelijke ruimten, materiële en technische voorzieningen aangepast aan het kind, medisch en verpleegkundig personeel geschoold en ervaren in het omgaan met kinderen, nime gelegenheid voor ouders om bij het kind te vertoeven. In de regio Limburg bestaat nog geen Intensive Care afdeling voor kinderen en wij achten het een van onze opgaven in het licht van de topreferentiefunctie van ons Academisch Ziekenhuis in deze behoefte te woorzien. Het is in deze tijd niet meer verantwoord om Intensive Care te bedrijven bij kinderen, die liggen temidden van de volwassenen of in een hoekje van een algemene intensive care afdeling, laat staan om deze kinderen tot ver buiten de provinciegrenzen te moeten vervoeren.

\section{Het chronisch zieke en gehandicapte kind}

Aangeboren afwijkingen, gevolgen van ongevallen, acute ziekten of chronische aandoeningen op de kinderleeftijd hebben vaak ernstige gevol gen voor het toekomstig lichamelijk, geestelijk en maatschappelijk welzijn. Rond het zeer ernstig gestoorde kind zijn de medisch-ethische problemen met het beginnen of voortzetten van levensreddende behandelingen, met 'doen of laten' vooral, maar niet uitsluitend, in de periode rond de geboorte nog volop in discussie. $\mathrm{Zij}$ vereisen bij ieder kind opnieuw zorgvuldige overwegingen door alle betrokkenen.

Handicaps zijn er in vele maten en gradaties. De grootste groep vormen de kinderen met mentale retardatie, het achterblijven in geestelijke ontwikkeling. Ondanks zorgvuldig onderzoek blijft in ongeveer de helft van de kinderen met mentale retardatie de oorzaak ervan (nog) onbekend, hetgeen de ouders van een dergelijk kind vaak moeilijk kunnen aanvaarden.

Een tweede grote groep vormen de patienten met stoornissen van het bewegingsapparaat t.g.w. aandoeningen van zenuw- of spierstelsel. Maarook afwijkingen van gehoor-en gezichtsvermogen, leerstoomissen, spraakstoornissen, gedrag, vormen een handicap.

Vele chronische aandoeningen kunnen voor de patient als kind, maar ook als volwassene een belemmering voor zijn ontplooiing betekenen. Voorbeelden zijn er genoeg: asthma, cystic fibrosis aangeboren hartgebreken, rheumatoïde arthritis; al zullen niet alle betroffenen vinden dat zij gehandicapt zijn. 
Toch vereisen zij extra voorzieningen en bijzondere zorg om de gevolgen van de stoornis te verhelpen of te beperken of om het kind en de omgeving ermee te leren omgaan.

Op het medisch vlak is het zeker niet de kinderarts alleen, die hierbij betrokken is.

In dit verband mag ik memoreren, dat de eerste oratie aan de Rijksuniversiteit Limburg, uitgesproken door de hoogleraar Keel-, Neus- en oorheelkunde, Prof. Marres, het taal- en spraakgestoorde kind tot onderwerp had. Specialisten op het gebied van de KNO, de logopedie, de oogheelkunde, de orthopedie, de fysiotherapie, de revalidatie, de kinderneurologie enz. hebben allen hun eigen inbreng. Opvoeding, schoolkeuze, beroepskeuze, zelfredzaamheid, financiële steun, aanpassing van behuizing, zo nodig plaatsing in een instituut, dat alles maakt het gehandicapte kind tot middelpunt van de zorg van niet alleen medische en paramedische disciplines, maar ook van opvoedkundige, onderwijzer, psycholoog, maatschappelijk werker, sociale instanties en patientenverenigingen.

Deze multidisciplinaire bemoeienis kan van grote waarde zijn voor het gehandicapte kind en zijn familie. Coördinatie van de hulpverlening is daarbij echter ononibeerlijk. Nog te veel ouders hebben het gevoel zelf hun weg te moeten zoeken in het bos van de hulpverleners en niet alle kunnen dat. De kinderarts als generalist, gespecialiseerd in de zorg voor het kind, kan hierbij een coördinerende rol vervullen.

De voorzieningen voor een gehandicapt kind en later voor de gehandicapte volwassene zijn kostbaar.

Het samenbrengen van alle expertise op dit terrein in een regionaal instituut zou kunnen leiden tot het stroomlijnen van de zorg en onderzoek naar gebreken of overtolligheden daarin bevorderen.

\section{Integrale kindergeneeskunde}

Vele andere disciplines leveren bijdragen aan de voorzieningen voor een integrale kindergeneeskunde in het Academisch Ziekenhuis Maastricht.

Een aantal daarvan kwam reeds ter sprake en ik zal hier niet naar volledigheid streven. Een bijzondere plats wordt ingenomen door de radiodiagnostiek, waarvan de medewerkers zo kindvriendelijk mogelijk de patientjes laten profiteren van de explosieve vooruitgang van de beelldvormende technieken. Ook verworvenheden van de moderne 
chirurgie zijn voor de kindergeneeskunde essentieel, met name de bijzondere kinderchirurgie en de hartchirurgie.

Extra wermelden wil ik hier de kinderneurologie, een langzamerhand zeer specifiek vakgebied met overlap naar de kindergeneeskunde en de neurologie, maar ook van belang voor klinische genetica en obstetrie. De kindemeurologie wordt bij ons met verve beoefend door collega Vles.

Het onderzoek van de kinderneuroloog is onmisbaar geworden bij het opsporen en evalueren van motorische- en ontwikkelingsstoornissen.

Stoornissen van de stofwisseling hebben veelal een genetische basis en de meeste openbaren zich in het eerste levensjaar. Van steeds meer aangeboren erfelijke ziek ten of afwijkingen is het chromosoom en soms zelfs de plaats op het chromosoom bekend waar het afwijkende genetisch materiaal is gelocaliseerd, dat verantwoordelijk is voor de stoornis. Dit biedt uiteraard grote mogelijkheden voor antenataal onderzoek en genetic counseling. De klinische genetica heeft zich ontwikkeld tot een zelfstandig specialisme, dat voor de kindergeneeskunde, maar ook voor andere vakgebieden van grote waarde is. Talrijke patienten met multipele congenitale afwijkingen konden met medewerking van of dankzij de klinisch geneticus gerubriceerd worden onder een bepaald syndroom, met consequenties voor verder onderzoek, prognose en genetische adviezen. Vele klinisch genetici zijn afkomstig uit de kindergeneeskunde, waardoor de afbakening van competenties wel eens kan vervagen.

Psychosociale vraagstukken in de kinderleeftijd zoals kindermishandeling, incest, suicide, om slechts de meest spectaculaire te noemen, vereisen deskundige inbreng van werkers uit de geestelijke gezondheidszorg.

Wij kunnen ons verheugen in de zeer gewaardeerde bijdrage van de psycholoog drs. Ghys, wiens hulp voor ons is als een baken in zee.

De activiteiten van een, op academisch niveau functionerende kinderpsychiatrie missen wij regelmatig.

Waarde toehoorders, ik heb geprobeerd U in vogelvlucht mee te nemen over het uitgestrekte terrein van de zorg voor het zieke kind. Meer dan een overzicht heb ik U niet kunnen bieden. De tijd is te kort om neer te strijken en een bepaald gebied meer gedetailleerd te bekijken. 
Mijnheer de Rector Magnificus, leden van het College van Bestum en wan de Universiteilsraad wan de Rijksuniversiteit Limburg.

Ik dank $U$ voor Uw medewerking bij mijn benoeming tot hooglerat in de Kindergeneeskunde aan deze Universiteit. U kunt ervan werzekerd zijn dat ik mij volledig zal inzetten om de mij opgedragen taken naar beste wermogen te vervullen.

Mijnheer de Dekaan, le den wan het Bestuur en de Raad wan de Faculteit der Geneeskunde, ik dank $U$ woor het in mij gestelde vertrouwen. Toen ik voor de eerste keer mijn opwachting maakte bij de benoemingscommissie en even moest wachten in de kamer van de secretaresse klonk uit de radio het 'Te Deum'. Veelbelovend vond ik dat. Bij mijn tweede bezoek stond hetzelfde klassieke programma aan, nu schalde echter de 'sabeldans "uit de luidspreker. Gelukkig ben ik niet erg bijgelovig. Ik hoop, dat ik op $\mathrm{U}$ mag blijven rekenen bij de verdere ontwikkeling van de kindergeneeskunde in Maastricht.

Leden van Bestuur en Directie van het Academisch Ziekenhuis Maastricht. Het is vooral de door $U$ toegezegde steun geweest die mij ertoe heeft gebracht de uitdaging van het ambt van hoogleraar Kindergeneeskunde en de functie van afdelingshoofd te aanwaarden. Een kinderafdeling stelt nu eenmaal hoge eisen aan ruimten en apparatuur maar vooral aan aantal, kwaliteit, attitude en inzet van de medewerkers. Ik waardeer het zeer dat $U$ daarvoor begrip heeft getoond. Ik vertrouw op Uw blijvende medewerking.

Hooggeleerde collegae Professoren en Afdelingshoofden van het Academisch Ziekenhuis Maastricht. Het goed functioneren van een Academische kinderafdeling is in ons aller belang. Ik doe een dringend beroep op Uw medewerking, die daarbij onmisbaar is. Onze eerste contacten zijn veelbelovend.

Hooggeleerde Tegelaers, mijn zeergewaardeerde opleider en promotor. In jou wil ik al de personen danken die aan mijn opvoeding tot paediater hebben bijgedragen, waartoe ik met name ook de collegae de Bruijne, Mochtar en Stoppelman zou willen rekenen. Jij zag de opkomst van pediatrische deelspecialismen aankomen en gaf mij gelegenheid om mij 
in de kindernefrologie te bekwarnen.

Vooral nu wij in Maastricht trachten om pediatrische deelspecialismen te ontwikkelen, besef ik pas goed wat ik je heb aangedaan toen ik, op uitnodiging van Prof. Weijers en Prof. Tiddens, besloot Amsterdam te verlaten en mijn werkzaamheden in het Wilhelmina Kinderziekenhuis te Utrecht voort te zetten. Je hebt het me, geloof $\mathrm{ik}$, nooit vergeven.

\section{Leden van Bestuur en Directie van het Wilhelmina Kinderziekenhuis.} Het Wilhelmina Kinderziekenhuis is de bakermat geweest van menig vooraanstaand kinderarts en hoogleraar kindergeneeskunde. Dit legt op mij een zware verplichting. Het was een voorrecht bijna 18 jaar bij $U$ te mogen werken in een omgeving waar het kind zonder discussie in het middelpunt staat.

Hooggeleerde Stoop en hooggeleerde van den Brande. Jullie hebben mij de ruimte gegeven om mijn functie als afdelingshoofd naar beste vermogen te vervullen en om mijn belangstelling voor het onderwijs gestalte te geven. Ik hoop iets van het heilig vuur, dat het WKZ zo"n vooraanstaande plaats in de Nederlandse Kindergeneeskunde heeft bezorgd, ook naar Maastricht te kunnen overdragen.

Zeergeleerde Donckerwolcke, zeergeleerde van Gool. Binnen ons nefrologisch team heb ik jarenlang met veel voldoening gewerkt. Vanaf deze plaats wil ik mijn dank uitspreken voor de samenwerking. Ik hoop, dat mijn banden met de pediatrische nefrologie, zoals jullie die beoefenen, behouden kunnen blijven.

De medewerking, belangstelling en sympathie, die ik van velen uit diverse sectoren wan het Wilhelmina Kinderziekenhuis mocht ontvangen, vervullen mij met dankbaarheid.

Hooggeleerde Ramaekers. Je leeftijd maakte het noodzakelijk het roer over te geven. Het was tragisch, dat je dat niet meer in goede gezondheid kon doen. Je hebt op je eigen wijze tientallen jaren het gezicht van de Kindergeneekunde in Maastricht bepaald, je hebt gestreden voor het belang van het kind en teleurstellingen zi.jn je daarbij niet bespaard gebleven. Het was je niet gegund mee te maken hoe wij de academisering van de kindergeneeskunde, die onder jou is begonnen, verder gestalte proberen te geven. 
Hooggeleerde Blanco. Door jouw benoeming tot hoogleraar in de kindergeneeskunde, in het bijzonder de neonatologie, is duidelijk aangegeven hoezeer ook onze faculteit belang hecht aan dit onderdeel van de Kindergeneeskunde. Ik hoop en verwacht dat onze samenwerking prettig en vruchtbaar zal zijn.

Geleerde Maertzdorf. In jouw persoon wil ik hier nog eens nadrukkelijk mijn waardering uitspreken voor de stafleden en alle andere medewerkers van de kinderafdeling, die in de moeilijke tijd tussen de ziekte van mijn voorganger en mijn benoeming met grote inzet de kinderafdeling niet alleen draaiende hebben gehouden, maar zelfs een begin wisten te maken van de opgaande lijn waarin wij ons nu bevinden. Voor de stimulerende hulp die de vakgroep daarbij mocht ontvangen van de emeritus hoogleraar Kindergeneeskunde uit Nijmegen, Prof. Schretlen, zij hem op deze plaats nog eens extra dank gezegd. Ik heb er begrip voor dat jullie ma jaren zonder duidelijke leiding, even moeten wennen aan de niewwe situatie en ik dank jullie voor de gelegenheid die je mij hebt gegeven om mijn werkzaamheden naar mijn beste inzicht en vermogen in te richten.

Dames en Heren van de Verplegingsdienst. Met bewondering en waardering bemerk ik dagelijks dat U ondanks alle ruimtelijke, materiele en personele problemen er toch steeds in slaagt de kindgerichte atmosfeer op de afdelingen te handhaven. Uw grote deskundigheid en inzet maken het mogelijk niet alleen geavanceerde kindergeneeskunde te bedrijven, maar daarnaast ook aandacht te kunnen schenken aan de hoge eisen, die verzorging en begeleiding van zieke kinderen en hun ouders stellen, ongeacht of het nu pasgeborenen, grotere kinderen of adolescenten betreft. $\mathrm{U} w$ enthousiasme om onze activiteiten verder te ontplooien doen mij de toekomst met vertrouwen tegemoet zien.

Dames en heren Studenten van de Faculteit der Geneeskunde. Ik hoop dat U uit mijn woorden heeft kunnen destilleren dat het onderwijs mij ter harte gaat. Wij zullen er naar streven dat het kind in Uw curriculum de plaats krijgt, die het verdient. 
Het sternt tot dankbaarheid, dat mijn moeder deze plechtigheid kan bijwonen. Aan $U$, moeder, en aan mijn overleden wader, die zich zoveel moeite hebben getroost om hun kinderen een goede opvoeding te geven, draag ik deze oratie op.

Lieve Hedy. Met toenemende bezorgdheid heb je mij steeds valker naar Maastricht zien reizen, totdat tenslotte het definitieve besluit viel om Utrecht te verlaten en naar Maastricht te gaan, iets wat in jouw ogen toch erg veel op emigreren leek. Ik ben je zeer dankbaar dat je mij bij deze besluitvorming zo hebt bijgestaan. Wanneer ik hier aan het werk ben, besef ik terdege dat dit zonder jouw liefdevolle steun niet mogelijk zou zijin.

Geachte toehoorders en $\mathrm{U}$ allen die betrokken bent bij de zorg voor het kind, het is onze taak om het kind, niet alleen in dit uur, middelpunt van onze aandacht te laten zijn.

Moge God's zegen op ons werk rusten.

Bedaank veur 't kómme, lech höb gezag.

(Bedankt voor Uw komst, Ik heb gezegd.) 


\section{Literatuurlijst.}

\section{Blanco C.E.}

Neonatologie: en volwassen specialisme. Inaugurale rede 1989, Maastricht.

Brodehl J.

Effective drugs for MCMS and their implications on the pathophysiology. Abstract VIII Congres of the IPNA, Toronto, Canada. Aug. 1989. $\$ 604$.

Centraal Bureau voor de Statisuick.

Statistisch zakbock 1988. Staatsuigeverij s' Gravenhage.

Editorial.

The pediatrician of the foture. J. Ped. 1985, 107:911-912

Forfar J.O.

Child health in a changing society. Oxford University Press, 1988

Gerne J.W.

On Science and subspecialism. J. Ped. 1987, 110.419-21.

"t Hart P.D.

Het zicke kind in goede handen. 100 Jaar gezondheidszorg in thet

Wilhelmina Kinderziekenhuis. Uitg. Catena Zwolle 1988

de Jonge G.A.

Leren luisteren. Afscheidscollege 1989. VU Amsterdam.

Marres E.H.M.A.

Het taal- en \$praakgestoorde kind. Inaugurale rede 1982, Maastricht

Ministerie WVC.

Notta 2000. 1986.

Ned. Ver. Kindergeneeskunde.

Discussienota beleidsconferentie. 1988

Ned. Ver. Kindergeneeskunde.

Doen of laten? Interimrapport van de werkgroep "Ethische aspecten van de neonatologie" 1988

Schnaper H.W. The immune system in minimal change nephrotic syndrome. Ped. Nephrology 1989, 3,1: 101-110.

Stoop J.W. en wan den Brande J.L.

Kindergeneeskunde anno 1984. Medisch Contact 1984, 39: 111.4.

Wieringen I.C. van.

De jeugdgezondhcidszorg zal ons cen zorg zijn.

Inaugurale rede 1988, Urech. 